\title{
Biomass and mortality of chum salmon in the pelagic Bering Sea
}

\author{
Masa-aki Fukuwaka ${ }^{1, *}$, Shunpei Sato ${ }^{2}$, Orio Yamamura ${ }^{1}$, Osamu Sakai ${ }^{3,4}$, \\ Toru Nagasawa ${ }^{1,2}$, Akira Nishimura ${ }^{1}$, Tomonori Azumaya ${ }^{1}$
}

${ }^{1}$ Hokkaido National Fisheries Research Institute, Fisheries Research Agency (FRA), 116 Katsurakoi, Kushiro 085-0802, Japan
${ }^{2}$ National Salmon Resources Center, FRA, 2-2 Nakanoshima, Toyohira-ku, Sapporo 062-0922, Japan
${ }^{3}$ Graduate School of Fisheries Science, Hokkaido University, 3-1-1 Minato-cho, Hakodate 041-8611, Japan
${ }^{4}$ Present address: National Research Institute of Far Seas Fisheries, FRA, 5-7-1 Orido, Shimizu-ku, Shizuoka 424-8633, Japan

ABSTRACT: To provide a key piece of information for understanding the functioning of the Bering Sea pelagic ecosystem, we estimated the biomass of immature chum salmon in the Bering Sea basin in autumn using a return-at-age analysis incorporated with the results of genetic stock identification studies. The estimated biomass was $742000 \mathrm{t}$ in 2002 and $617000 \mathrm{t}$ in 2003, which is possibly an underestimate because of the uncertainty of trawl selectivity parameters used in the estimation. Although chum salmon has been the dominant nekton species in the pelagic ecosystem of the Bering Sea basin in recent years, biomass estimates for the species were smaller than one-tenth of the maximum biomass of walleye pollock in the 1980s. Previous studies have highlighted the importance of the huge biomass of mesopelagic planktivores, such as myctophid fishes and gonatid squid, to the ecosystem function of the pelagic Bering Sea. Planktivorous Pacific salmon including chum and pink salmon may also play a significant role as competitors and predators of small planktivores, thus affecting the dynamics of ecosystem function and nekton community structure in the pelagic Bering Sea.

KEY WORDS: Pelagic ecosystem • Planktivores · Biomass estimate · Salmon · Catch-at-age analysis · Genetic stock identification · Markov chain Monte Carlo

\section{INTRODUCTION}

The Bering Sea is one of the world's most biologically productive areas. The Bering Sea ecosystem supports not only high fisheries production of walleye pollock Theragra chalcogramma, Pacific salmon Oncorhynchus spp., flatfishes, and other fish species, but also provides a feeding ground for seabirds and marine mammals (Livingston 2004, Aydin \& Mueter 2007). The ecosystems of eastern Bering Sea shelf areas have been well studied due to their importance as fishing grounds used by domestic commercial fisheries from the United States (e.g. Aydin \& Mueter 2007). However, the species composition of the nekton community differs between basin and shelf areas in the Bering Sea, and walleye pollock and Pacific salmon are the dominant species in the pelagic ecosystem of the basin area (Brodeur et al. 1999). The quantity of commercial catches of walleye pollock in the high-seas area of the Bering Sea peaked in 1989 at 1.45 million tonnes (t), declined sharply after that, and has been closed since 1993 (Wespestad 1993).

Chum salmon Oncorhynchus keta is the second most abundant salmon species in the North Pacific (Fukuwaka et al. 2007). Chum salmon migrate, feed on zooplankton, and exhibit high growth rates in the Bering Sea during the summer-autumn period (Groot \& Margolis 1991). From the 1950s to the early 1990s, high-seas gillnet salmon fisheries caught mainly chum, sockeye, and pink salmon in the Bering Sea and central North Pacific. Chum salmon catch in this region peaked in 1956 at 11.7 million (22000 t) and was 
9.3 million (17000 t) in 1972 (Fukuwaka \& Morita 2008). The high-seas salmon gillnet fisheries were closed when the Convention for the Conservation of Anadromous Stocks in the North Pacific Ocean (NPAFC Convention) was enforced in 1993. However, the density index, i.e. number of chum salmon caught by research gillnets, increased in the 1980s and in the early 2000s reached levels 3- to 8-fold of those in 1972 (Fukuwaka et al. 2007). A biomass estimation of chum salmon in the Bering Sea would provide key information to aid in understanding the functioning of the Bering Sea pelagic ecosystem.

Chum salmon originating from rivers in Pacific Rim nations migrate to the North Pacific and adjacent seas and finally return to their natal rivers to spawn after 2 to $5 \mathrm{yr}$ of ocean life (Groot \& Margolis 1991). From summer to autumn, chum salmon originating from many regions enter and mix in the Bering Sea (Seeb et al. 2004). For the international management of highseas salmon fisheries, stock identification techniques have been well developed using tagging experiments, scale pattern analysis, otolith marking, and genetic techniques (e.g. Tanaka et al. 1969, Myers et al. 1996, Urawa et al. 2000, Seeb et al. 2004). After the closure of high-seas gillnet fisheries, the oceanic abundance of immature chum salmon could be estimated from the number of returns-at-age with an assumed or estimated value of natural mortality. However, return-atage data are not always available for all chum stocks around the North Pacific. The basic idea of the present study was that information on stock identification could be incorporated with a return-at-age analysis to estimate the total oceanic abundance of immature chum salmon in the Bering Sea.

The Bayesian approach can combine previous research results as prior information into a stockassessment model. For example, Michielsens et al. (2008) assessed a mixed stock consisting of 4 wild Atlantic salmon stocks in the Baltic Sea using the Markov chain Monte Carlo (MCMC) analysis, combining the results of several previous studies. The objectives of the present study were to (1) use the MCMC return-at-age analysis to estimate the total biomass of immature chum salmon, one of the dominant pelagic planktivores in the Bering Sea basin; and (2) estimate demographic parameters such as the mortality, abundance-at-age, and catchability of a research trawl of chum salmon during their ocean life.

\section{MATERIALS AND METHODS}

Oceanic life history of chum salmon. For the returnat-age analysis, we examined Japanese hatchery stocks, for which statistics on juvenile releases, coastal catch, river catch, and age composition of adults were available. Juvenile chum salmon released from hatcheries to rivers migrate out to the sea in the spring. Japanese chum salmon juveniles move to the Okhotsk Sea in the summer of their first year of ocean life (Urawa et al. 2001); in the late autumn and winter of the first year they are distributed in the western North Pacific. The mortality of chum salmon during the first year is considered to be higher than at later ages in their oceanic life (Fukuwaka \& Suzuki 2002). After spending one winter in the ocean, immature chum salmon enter the Bering Sea in the summer of their second year of ocean life (Urawa et al. 2001). Japanese immature chum salmon are distributed in the Bering Sea in the summer and in the eastern North Pacific in the winter during their oceanic phase. Because almost all juveniles in Japanese stocks are released from salmon hatcheries (Hiroi 1998), we assumed that all of the Japanese chum salmon that occur in the Bering Sea are from hatchery stock. After 2 to $5 \mathrm{yr}$ of ocean life, maturing chum salmon migrate toward their natal rivers and are caught in coastal waters by commercial fisheries, which, in Japan, mainly use trap nets. Mature chum salmon caught in rivers, mainly in weirs, are used for hatchery broodstock.

Bering Sea survey. The study region was set in the basin area (including the shelf slope; $>200 \mathrm{~m}$ depth) of the Bering Sea because immature chum are distributed mainly on the outer shelf and in the oceanic areas of the Bering Sea (Murphy et al. 2003). Member nations of the North Pacific Anadromous Fish Commission (NPAFC) conducted a 5 yr cooperative salmon research study in the Bering Sea under the Bering-Aleutian Salmon International Survey (BASIS) plan from 2002 to 2006 under the NPAFC Convention (NPAFC 2001). One of the objectives of BASIS was to determine the role of salmon in nektonic communities and their association with the Bering Sea's ecosystem status. The RV 'Kaiyo Maru' of the Fisheries Agency of Japan surveyed salmon abundance in the eastern part of the Bering Sea basin from August to September 2002 and 2003 as part of the BASIS survey. Although a Russian research vessel surveyed chum salmon stocks in the western part of the basin during a similar time period (Starovoytov 2007, Zavolokina \& Zavolokin 2008), no complete sets of survey data on chum salmon catch, age, size, and stock composition were available. We assumed density, age, size, and stock composition of immature chum salmon were not different between the eastern and western parts of the Baring Sea basin, and extrapolated these data from our survey area to the western basin.

There were 38 trawl operations in the survey area in 2002 and 22 in 2003 (Fig. 1). A midwater trawl was towed at 5 knots from the surface to ca. $50 \mathrm{~m}$ deep for 


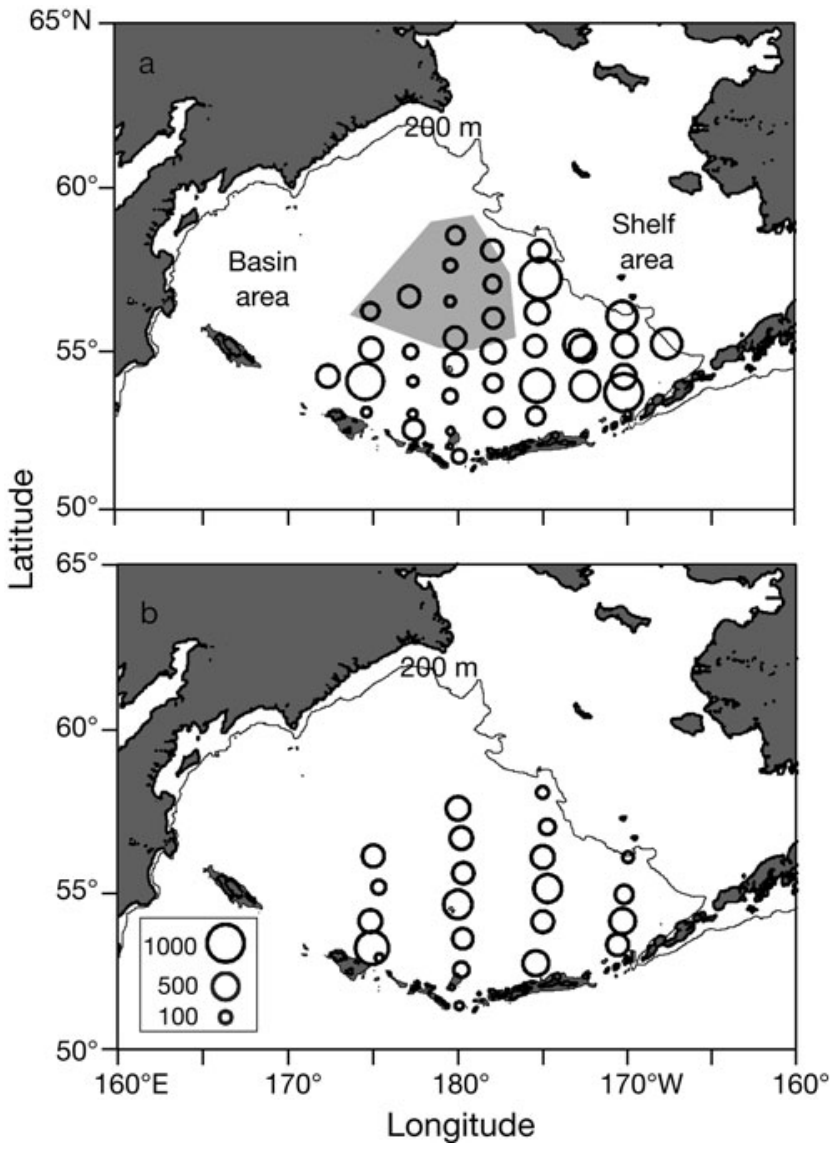

Fig. 1. Oncorhynchus keta. Bering Sea, showing chum salmon catch by research trawl operations in (a) 2002 and (b) 2003. Size of circle indicates number of chum salmon caught per $1 \mathrm{~h}$ research trawl. Shelf area is the area between the shoreline and the $200 \mathrm{~m}$ isobath, the basin area is the area surrounded by the $200 \mathrm{~m}$ isobath, and the high-seas area is the outside of the 200 mile zone from the shoreline shaded in (a)

$1 \mathrm{~h}$ during the daytime to catch chum salmon. The trawl opening was ca. $50 \mathrm{~m}$ in height and width, with a net length of $222 \mathrm{~m}$, maximum mesh size of $26 \mathrm{~m}$ at the mouth, with mesh size progressively reducing towards the end of the net, and a codend liner of $12 \mathrm{~mm}$ mesh. All chum salmon that were caught were removed from the net and counted. From a subsample of a maximum of 60 fish in 2002 and 120 fish in 2003 per trawl operation, fork length and body weight were measured to the nearest $\mathrm{mm}$ and $10 \mathrm{~g}$, respectively, and 2 scales were collected. From 18 trawl stations in 2002 and 16 in 2003 selected to cover the Bering Sea survey area, a blood sample for genetic stock identification was also collected from a maximum of 60 fish in the subsamples (Moriya et al. 2007). Age of fish was determined by counting annuli against a scale impression on an acetate card. The European system was used for age designation, in which the number preceding the deci- mal point indicates the number of winters spent in freshwater and the number following the decimal point indicates the number of winters spent in the sea (Groot \& Margolis 1991).

Bayesian return-at-age analysis. For return-at-age data, we used the coastal catch from commercial fisheries, river catch for hatchery broodstock, and age composition of hatchery broodstock for Japanese chum salmon. The number of returning chum salmon was the sum of the coastal and river catches because the number of naturally-spawned adults was insignificant (Hiroi 1998). The age composition of mature chum salmon was weighted by the river catches for each hatchery broodstock. Catch statistics and age composition of chum salmon during the 2002-2006 seasons and the number of released juveniles for 1999-2001 brood years were obtained from the NSRC (NSRC 2001, 2002, 2003, 2004, 2005, 2006, FRA 2008, in press).

To estimate the demographic parameters and total biomass of immature chum salmon, we used a catchat-age model modified for salmon return-at-age data and the MCMC technique incorporated with the results of genetic stock identification studies. To avoid parameterization of age-specific maturation rate, i.e. returns/(returns + immatures), we modelled the abundance-at-age of immature chum salmon backwards from the return-at-age of mature fish for Japanese stocks (Eq. 1 in Table 1). Early ocean mortality from release to September (age 0.1 , ca. $17 \mathrm{mo}$ ) was the ratio of estimated abundance of age 0.1 fish to the number of released juvenile chum salmon for a year class (Eq. 2 in Table 1). The abundance-at-age for non-Japanese stocks was calculated using an MCMC output of stock composition estimates by age group from genetic stock identification data (Eq. 3 in Table 1). Biomass was estimated from the abundance-at-age, fork length composition of each age group, and body weight-fork length relationships from the ocean survey (Eqs. 4, 5, \& 6 in Table 1). We did not estimate the biomass of juvenile (age 0.0) chum salmon because they are distributed mainly in shelf habitats and less in the basin area of the Bering Sea (Murphy et al. 2003, Zavolokina \& Zavolokin 2008).

Stock composition by age group was estimated using the MCMC method. Using the genetic samples, we previously analysed stock composition by the conditional maximum likelihood method using the baseline data in Sato et al. (2004) (Moriya et al. 2007). The Bayesian MCMC method can explicitly model sampling error in baseline genetic composition and evaluate the variance in stock composition estimates caused by such a sampling error. To estimate age-specific stock compositions simultaneously with a common set of baseline genetic compositions, the 'many-to-many' model was used for a mixed stock analysis of chum 
Table 1. Oncorhynchus keta. (a) Model equations and (b) parameters used in the Markov chain Monte Carlo return-at-age analysis for immature chum salmon in the Bering Sea in 2002 and 2003

Equation Description

(a) Model equations

(1) $N_{\mathrm{J}, y, a}=\left(N_{\mathrm{J}, y+1, a+1}+R_{y+1, a+1}\right) \exp \left(M_{a}\right) \quad$ Abundance at age for Japanese (J) stock

(2) $M_{0, y}=\ln \left(J_{Y}\right)-\ln \left(N_{J_{, Y}+1, a=1}\right) \quad$ Early ocean mortality during the 1st year

(3) $N_{\mathrm{Ror} A, y, a}=N_{\mathrm{J}, y, a} p_{\mathrm{Ror} A, y, a} / p_{\mathrm{J}, y, a} \quad$ Abundance of Russian (R) or North American (A) stock

(4) $B_{y, a}=\sum_{l}\left(w_{l} \alpha_{1, y, a} \sum_{C} N_{C, y, a}\right) \quad$ Biomass estimates in the Bering Sea

(5) $\alpha_{1, y, a}=\frac{1}{\sqrt{2 \pi} \sigma_{\mu_{y, a}}} \int_{l-10}^{1+10}\left(-\frac{\left(F L-\mu_{y, a}\right)^{2}}{2 \sigma_{\mu_{y, a}}^{2}}\right) \mathrm{d} F L \quad$ Fork length composition of chum salmon

(6) $w_{1}=\exp \left(\beta_{1, y}+\beta_{2} \ln (l)\right) \quad$ Weight-length relationship

(7) $o_{i, 1, y, a} \sim \operatorname{Multi}\left(n_{i, Y}, \gamma_{1, Y, a}\right)$

Age and length composition from ocean survey by trawl operation

(8) $\gamma_{l, y, a}=\frac{s_{1} \alpha_{1, y, a} \sum_{C} N_{C, y, a}}{\sum_{l, a}\left(s_{l} \alpha_{l, Y, a} \sum_{C} N_{C, y, a}\right)}$

Expected age and length composition of research trawl catch

(9) $s_{1}=\frac{1}{\sqrt{2 \pi} \sigma} \int_{-\infty}^{l} \exp \left(-\frac{\left(1-l_{C}\right)^{2}}{2 \sigma^{2}}\right) \mathrm{d} l$

Probit trawl selectivity function

(10) $O_{i, y} \sim \log \mathrm{N}\left(T_{Y}, \sigma_{T Y}^{2}\right)$

Research trawl catch by operation

(11) $T_{y}=q \frac{a r}{A R} \sum_{l, a}\left(s_{1} \alpha_{l, y, a} \sum_{C} N_{C, Y, a}\right)$

Expected catch for a research trawl operation

Parameter

Description

$\begin{array}{ll}\text { (b) Parameters } & \text { Abundance for stock } C \text { (J: Japanese, R: Russian, and A: Nor } \\ N_{C, Y, a} & \text { in year } y \\ R_{Y, a} & \text { Return-at-age a of Japanese chum stocks in year } y \\ M_{a} & \text { Ocean mortality coefficient at age } a \\ J_{Y} & \text { Number of juveniles released in year } y \text { from Japanese chum } \\ p_{C, Y, a} & \text { Stock composition of immature chum salmon for stocks } C \text { at } \\ & \text { year } y \\ \mu_{Y, a} & \text { Mean fork length at age a and year } y \\ \sigma_{\mu y, a} & \text { Standard deviation of } \mu_{Y, a} \\ F L & \text { Fork length of chum salmon } \\ l & \text { Midpoint of fork length class (class interval = 20 mm) } \\ \beta_{1, Y} & \text { Intercept of allometric weight-length relationship } \\ \beta_{2} & \text { Common slope of allometric weight-length relationship } \\ n_{i, y} & \text { Number of chum salmon sampled in operation } i \text { and year } y \\ l_{C} & \text { 50\% selection length of research trawl } \\ \sigma & \text { Selection range parameter of probit selectivity function } \\ \sigma_{T y} & \text { Standard deviation of log-scale } T_{y} \\ q & \text { Catchability of research trawl operation } \\ a r & \text { Size of area swept by a trawl operation } \\ A R & \text { Size of total basin area in the Bering Sea }\end{array}$


salmon catches in the Bering Sea from multiple stocks in the Pacific Rim nations (Bolker et al. 2007).

The age-specific abundance of immature chum salmon for Russian or North American stocks were estimated from the abundance of Japanese immatures estimated by the return-at-age analysis and composition estimates for stock mixtures in the ocean samples. The set of stock compositions used in a simulation was drawn randomly from the series of estimates produced by the MCMC stock composition analysis in order to incorporate the MCMC stock composition estimates into the MCMC return-at-age analysis as an informative prior (Michielsens et al. 2008). Because the difference in genetic composition between Korean and Japanese rivers was insignificant (Sato et al. 2004), we could not estimate reliable compositions of Korean and Japanese stocks. Since the abundance of the Korean stock was much lower than that of the Japanese stock (Fukuwaka et al. 2007), we combined the Japanese and Korean stocks, and used the sum of the compositions assigned to Japanese and Korean rivers to represent the result of the MCMC stock composition analysis for Japanese stock. For other stocks, we used the sum of the stock compositions assigned to Russian rivers to represent the proportion of Russian stock, and the sum of those assigned to North American rivers to represent the proportion of North American stock.

To fit the model to observed ocean survey data, we constructed data models of the number of individuals caught and the age and length compositions of chum salmon from individual trawl operations conducted in the ocean survey (Eqs. $7 \& 8$ in Table 1). The frequency of age and length composition with a class interval of $20 \mathrm{~mm}$ had a multinomial error because we measured a limited number of subsamples onboard the research vessel. Expected composition by age and length class was calculated from abundance-at-age, size composition for each age group, and survey trawl selectivity parameters (Eqs. 1, 3, 5, \& 9 in Table 1). We assumed that the number of chum salmon caught in an individual research trawl operation had a log-normal error, considering the patchy distribution of fish or ocean structure (Eq. 10 in Table 1). The expected number of salmon caught was the product of catchability, size selectivity of research trawl, and density of fish, which was the product of the expected number of catchable stock and the ratio of the area surveyed to the total basin area of the Bering Sea (Eq. 11 in Table 1). Other data, parameters, and prior information used for this estimation are shown in Table 2 .

We estimated parameters in models using 2 Bayesian MCMC analyses with observed data: (1) age and size composition and catch per research trawl operation in the ocean survey for the return-at-age analysis, and (2) genetic composition of the baseline and ocean survey samples in the stock composition analysis. A Bayesian MCMC analysis produces a Markov chain of parameters that represents a random walk through the posterior distribution after the convergence (Clark 2007). The posterior distribution represents the probability of observing a particular set of parameters given the data, and which can be solved by combining information from the prior distribution of parameters and the likelihood of the data given a set of parameters based on the Bayes' theorem.

For MCMC estimations of the return-at-age and stock composition analyses, we used the WinBUGS 1.4.3 and the R2WinBUGS package in R 2.8.1 (Lunn et

Table 2. Oncorhynchus keta. Constants and prior information used in the Markov chain Monte Carlo return-at-age analysis and stock composition estimation. Distribution type is in parentheses where applicable. C: constant; I: informative prior; N: noninformative prior

\begin{tabular}{|c|c|c|c|}
\hline Parameter & Value & Prior & Source \\
\hline ar & $0.463 \mathrm{~km}^{2}$ & $\mathrm{C}$ & Product of trawl mouth width, tow speed, and time \\
\hline$A R$ & $1281000 \mathrm{~km}^{2}$ & $\mathrm{C}$ & McRoy \& Goering (1975) \\
\hline$\beta_{1, y}$ & -11.7 for $2002,-11.8$ for 2003 & $\mathrm{C}$ & Fork length-body weight relationship (see 'Results') \\
\hline$\beta_{2}$ & 3.06 & $\mathrm{C}$ & As above \\
\hline$\mu_{y, a}, \sigma_{\mu y, a}$ & $\begin{array}{l}371 \pm 28 \mathrm{~mm} \text { for age } 0.1 \\
492 \pm 38 \mathrm{~mm} \text { for age } 0.2 \\
552 \pm 38 \mathrm{~mm} \text { for age } 0.3 \\
571 \pm 51 \mathrm{~mm} \text { for ages } 0.4 \text { and } 0.5 \text { (normal) }\end{array}$ & I & Ishida et al. (1998) \\
\hline$M_{a}$ & $0.238 \pm 0.089$ (normal) & I & $\begin{array}{l}\text { Mean } \pm \text { SD of ocean mortality estimates } 0.201,0.364 \\
\text { (Parker 1962a), } 0.231 \text { (Parker 1962b), and } 0.156 \text { (Ricker 1976) }\end{array}$ \\
\hline$l_{c}$ & $340 \pm 14 \mathrm{~mm}$ (normal) & I & Fukuwaka et al. (2008) \\
\hline$\sigma$ & $9.64 \pm 8.61 \mathrm{~mm}($ normal $)$ & $\mathrm{I}$ & Fukuwaka et al. (2008) \\
\hline$\sigma^{2} T_{Y}$ & $\alpha=\beta=0.1$ (inverse gamma) & $\mathrm{N}$ & - \\
\hline$q$ & $0.001-1$ (uniform) & $\mathrm{N}$ & - \\
\hline$p_{C, y, 5}$ & $1 / 3$ (Dirichlet) & $\mathrm{N}$ & - \\
\hline
\end{tabular}


al. 2000, Sturtz et al. 2005, R Development Core Team 2008). For the MCMC estimation of the return-at-age analysis, we simulated 3 chains of 10000 iterations and a 5000 iteration burn-in period with Gelman \& Rubin's (1992) convergence diagnostics using the coda package in R (Plummer et al. 2009). In the MCMC estimation of the stock composition analysis, we simulated 3 chains of 100000 iterations and, due to bimodality in the posterior distribution of parameters, discarded estimates of iterations before the convergence of the simulation for each chain using Heidelberger \& Welch's (1983) process using the coda package in $\mathrm{R}$.

Sensitivity analysis. To evaluate the sensitivity of the model to size selectivity of the research trawl, we compared age-specific mortality and total biomass estimates with those estimated under 2 cases of smaller and larger $50 \%$ selection lengths. Here, we used trawl selectivity parameters estimated in Fukuwaka et al. (2008) as informative priors. However, because less chum salmon $<400 \mathrm{~mm}$ in fork length were caught by research gear in that study, the trawl selectivity parameters for small fish may be uncertain. Thus, we estimated mortality and biomass under 2 cases of constant trawl selectivity parameters: lower and upper confidence limits of $50 \%$ selection length with a common selection range parameter estimated in Fukuwaka et al. (2008).

\section{RESULTS}

\section{Return-at-age and ocean survey data}

The number of mature chum salmon returning to the Japanese coast and rivers ranged from 57.3 million to 76.6 million during the 2002-2006 seasons (Fig. 2). The dominant ages of mature fish were 0.3 and 0.4 , with age 0.3 accounting for 37.9 to $62.2 \%$ and age 0.4 for 28.7 to $53.5 \%$ of the total number of returns. The combined number of returns for ages 0.3 and 0.4 was 80.7 million in the 2001 year class, which was the largest of the 1998-2001 year classes.

Mean $( \pm \mathrm{SD})$ number of fish caught per research trawl in the Bering Sea basin was $205 \pm 153$ (range $=22$ to 670) in 2002 and $202 \pm 161$ (range = 15 to 440) in 2003 (Fig. 1). Chum salmon were caught in all trawls. A bimodal fork length composition was observed in immature chum salmon in the ocean surveys (Fig. 3). The smaller mode was in the $350 \mathrm{~mm}$ size class and consisted mainly of age 0.1 fish, whereas the larger mode was in the $450 \mathrm{~mm}$ size class in 2002 and the $470 \mathrm{~mm}$ size class in 2003 and consisted mainly of age 0.2 fish. There were fewer fish in the smaller mode than in the larger mode in 2002; this was reversed in 2003. Age 0.1 fish in 2003 were members of the 2001 year class, which was the strongest of the examined year classes.
The relationship between fork length and body weight was significantly different between 2002 and 2003. The difference in the slope of the log-transformed body weight on log-transformed fork length was statistically insignificant (ANCOVA, p = 0.156); however, the difference in the intercepts was significant $(p<0.001)$. Thus we used a common slope but different intercepts for the weight-length relationship (Eq. 6 in Table $1 ; \beta$-values in Table 2).

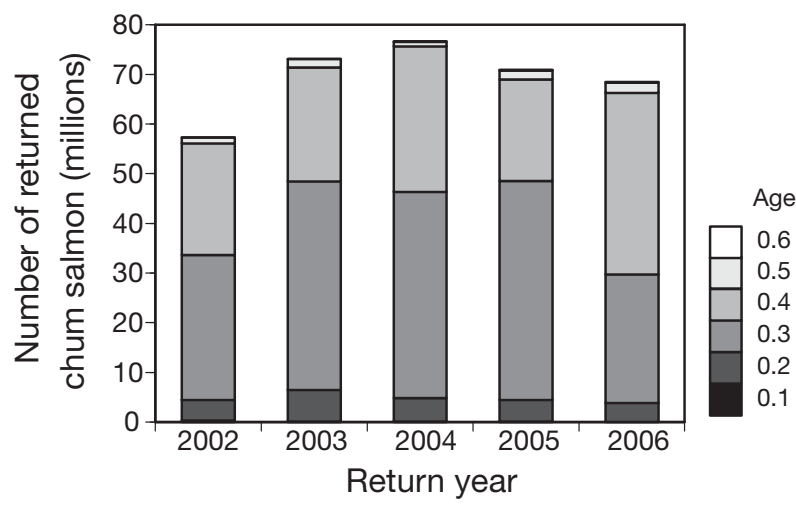

Fig. 2. Oncorhynchus keta. Number of returns-at-age of chum salmon to Japanese coastal waters and rivers for the 2002-2006 seasons. Age is defined as e.g. 0.1 (0 winters in freshwater. 1 winter at sea)

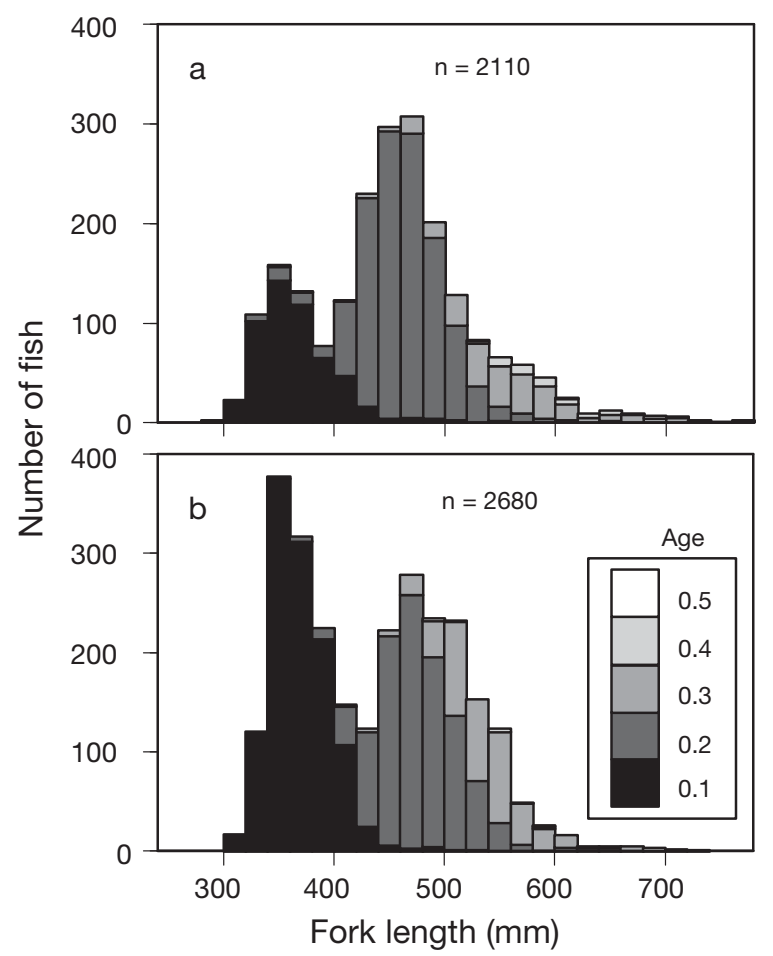

Fig. 3. Oncorhynchus keta. Fork length and age composition of chum salmon in subsamples from research trawl catches in (a) 2002 and (b) 2003 
Table 3. Oncorhynchus keta. Markov chain Monte Carlo estimates (mean $\pm \mathrm{SD}$ ) of stock composition by age group sampled in the Bering Sea basin in 2002 and 2003

\begin{tabular}{|lccc|}
\hline Year/Age & Japan & Russia & North America \\
\hline $\mathbf{2 0 0 2}$ & & & \\
0.1 & $0.437 \pm 0.046$ & $0.282 \pm 0.050$ & $0.281 \pm 0.044$ \\
0.2 & $0.451 \pm 0.073$ & $0.363 \pm 0.087$ & $0.186 \pm 0.034$ \\
0.3 & $0.394 \pm 0.041$ & $0.237 \pm 0.044$ & $0.368 \pm 0.049$ \\
0.4 & $0.310 \pm 0.049$ & $0.178 \pm 0.044$ & $0.512 \pm 0.058$ \\
$\mathbf{2 0 0 3}$ & & & \\
0.1 & $0.409 \pm 0.035$ & $0.209 \pm 0.051$ & $0.381 \pm 0.046$ \\
0.2 & $0.385 \pm 0.034$ & $0.241 \pm 0.049$ & $0.373 \pm 0.047$ \\
0.3 & $0.413 \pm 0.040$ & $0.157 \pm 0.040$ & $0.431 \pm 0.047$ \\
0.4 & $0.287 \pm 0.049$ & $0.178 \pm 0.046$ & $0.535 \pm 0.058$ \\
\hline
\end{tabular}

The MCMC stock composition analysis by age group of the chum salmon catch from the Bering Sea trawl survey of 2002-2003 showed that the proportion of Japanese stock was 28.7 to $45.1 \%$ (Table 3 ). The estimated proportions of Japanese stock were largest in age groups 0.1 to 0.3 in 2002 and in age groups 0.1 to 0.2 in 2003, but not in age group 0.4 in 2002 or age groups 0.3 and 0.4 in 2003 .

\section{MCMC estimates of biomass and population parameters}

The mean $( \pm \mathrm{SD})$ total abundance of all immature chum salmon estimated by the return-at-age and stock composition analyses was $580 \pm 41$ million in 2002 and $595 \pm 44$ million in 2003. The dominant age group was 0.2 in 2002 and 0.1 in 2003 (Fig. 4). The estimated abundance of age 0.2 fish in 2003 was larger than that of age 0.1 fish in 2002 for the 2000 year class, which indicates an underestimation of age 0.1 abundance in 2002 or an overestimation of age 0.2 abundance in 2003.

The mean $( \pm \mathrm{SD})$ total biomass of all immature ages of chum salmon was estimated at $742 \pm 53$ thousand $\mathrm{t}$ (percentile confidence interval $[\mathrm{PCI}]=645$ to 852$)$ in 2002 and $617 \pm$ 45 thousand $\mathrm{t}$ ( $\mathrm{PCI}=538$ to 715$)$ in 2003 (Table 4). The estimated ocean mortality of chum salmon for ages 0.2 to $0.5\left(M_{2}\right.$ to $M_{5}$, Table 4) was similar to values based on prior information (Table 2). For age 0.1, estimated mortality $\left(M_{1}\right.$, Table 4$)$ was much lower than the estimates for ages 0.2 to $0.5\left(M_{2}\right.$ to $\left.M_{5}\right)$. Early ocean mortality of juveniles from the time of release to the autumn of age $0.1\left(M_{0}\right)$ was much higher than for other ages, including early mortality and winter mortality in the first ocean year. In addition to these popula-

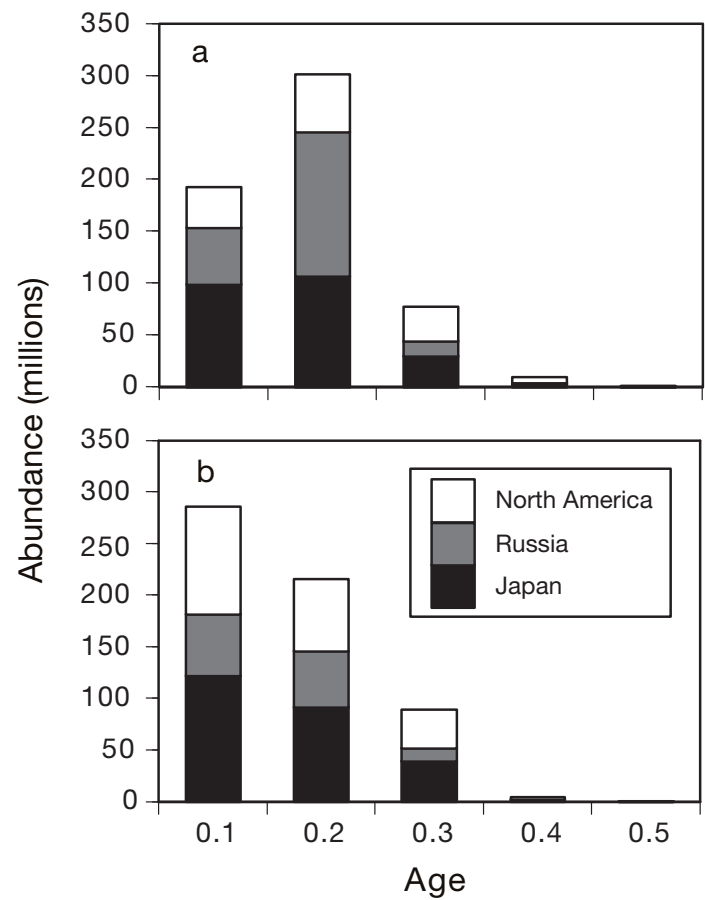

Fig. 4. Oncorhynchus keta. Estimated age-specific abundance of immature chum salmon in the Bering Sea basin in the autumn of (a) 2002 and (b) 2003

tion parameters, the mean $( \pm \mathrm{SD}) \mathrm{MCMC}$ estimate of the catchability of the research trawl $(q)$ was $0.363 \pm$ 0.050 .

In the sensitivity analysis, the mortality estimate for age 0.1 chum salmon $\left(M_{1}\right)$ differed among assumptions about trawl selectivity (Table 4 ). Using the upper confidence limit as a constant $50 \%$ selection length of

Table 4. Oncorhynchus keta. Markov chain Monte Carlo estimates (mean $\pm \mathrm{SD}$ ) of early ocean mortality $\left(M_{0}\right)$, age-specific ocean mortality coefficient $\left(M_{a}\right)$, and total biomass ( $\Sigma B_{y i}$ thousand tonnes) for immature chum salmon in the Bering Sea basin, and results of sensitivity analysis to lower (LCL) and upper confidence limits (UCL) of $50 \%$ selection length of research trawl $\left(l_{c}\right)$ estimated by Fukuwaka et al. (2008). BY: brood year

\begin{tabular}{|lccc|}
\hline \multirow{2}{*}{ Parameter } & \multirow{2}{*}{ Estimate } & \multicolumn{2}{c|}{$\begin{array}{c}\text { Sensitivity } \\
\text { LCL }\end{array}$} \\
& & & Unalysis to $l_{C}$ \\
& & $2.92 \pm 0.07$ & $2.68 \pm 0.08$ \\
$M_{0,1999 \mathrm{BY}}$ & $2.91 \pm 0.06$ & $2.71 \pm 0.07$ & $2.48 \pm 0.08$ \\
$M_{0,2000 \mathrm{BY}}$ & $2.71 \pm 0.07$ & $3.88 \pm 0.04$ & $3.63 \pm 0.06$ \\
$M_{0,2001 \mathrm{BY}}$ & $3.87 \pm 0.04$ & $0.00616 \pm 0.00588$ & $0.265 \pm 0.041$ \\
$M_{1}$ & $0.00627 \pm 0.00647$ & $0.268 \pm 0.048$ & $0.253 \pm 0.052$ \\
$M_{2}$ & $0.271 \pm 0.047$ & $0.198 \pm 0.072$ & $0.166 \pm 0.069$ \\
$M_{3}$ & $0.197 \pm 0.071$ & $0.370 \pm 0.078$ & $0.339 \pm 0.081$ \\
$M_{4}$ & $0.367 \pm 0.079$ & $0.255 \pm 0.090$ & $0.256 \pm 0.086$ \\
$M_{5}$ & $0.254 \pm 0.088$ & $742 \pm 53$ & $746 \pm 53$ \\
$\Sigma B_{2002}$ & $742 \pm 53$ & $617 \pm 45$ & $744 \pm 53$ \\
$\Sigma B_{2003}$ & $617 \pm 45$ & & \\
\hline
\end{tabular}


research trawl $\left(l_{C}\right)$, the mortality estimate for age 0.1 fish was similar to that for ages 0.2 to 0.5 . Other agespecific mortality estimates were less different among assumptions for trawl selectivity. The biomass estimates were larger for the upper confidence limit of $l_{C}$ than for other assumptions. However, age-specific mortality and total biomass estimates for the lower confidence limit of $l_{C}$ were similar to those for the initial model, which indicates the data in the present study were better fit to a model with a small value of $l_{c}$.

\section{DISCUSSION}

\section{Population parameter estimates and reliability of biomass estimates}

The chum salmon biomass estimates in the present study were approximately consistent with another biomass estimate from the western Bering Sea (Starovoytov 2007, Zavolokina \& Zavolokin 2008). The estimated biomass of immature chum salmon in the present study was $742000 \mathrm{t}$ in the autumn of 2002 and $617000 \mathrm{t}$ in the autumn of 2003 in the Bering Sea basin. As part of the NPAFC BASIS plan, Russian research vessels conducted extensive surveys in the Russian 200 mile zone in the western Bering Sea using midwater trawls. Although we did not use the results of these Russian surveys in the present study because of their lack of stock composition data, Starovoytov (2007) and Zavolokina \& Zavolokin (2008) estimated the biomass of immature chum salmon to be $316830 \mathrm{t}$ in the autumn of 2002 and $246280 \mathrm{t}$ in the autumn of 2003 from the research trawl surveys in Russian waters. These biomass estimates for Russian waters were about $40 \%$ of our estimates. As the area of the Russian waters comprises slightly less than half of the area of the Bering Sea basin, the 2 estimates seem to be consistent.

An error in stock composition estimates could affect biomass estimates. In our ocean survey area, Russian stocks were significantly abundant in the western region (Moriya et al. 2007). Because we assumed in the present study that stock composition was not different between the eastern and the western part of the basin, the composition of Russian stock in the western part of the Bering Sea basin could be underestimated. In addition, the size composition of immature chum salmon, especially of younger ages, might be different among fish of different origin. For example, juveniles fed in hatcheries may be larger than wild fish at the time of oceanic outmigration and the proportion of hatchery released fish was larger in Japanese stock than Russian stock. Fish size in Russion stock could also be smaller than in Japanese stock because of the geographical difference in early ocean growth. The num- ber of circuli on the scale, a proxy of body growth, during the first year of ocean life has been shown to be larger for chum salmon stocks from southern areas than northern areas (Tanaka et al. 1969). When fish size in Russian stock was underestimated, the underestimation of Russian stock composition could have a greater effect on the total biomass estimates.

Another source of error in total biomass estimation was the uncertainty of size selectivity of fishing gear in the ocean survey. The mortality estimate for age 0.1 fish (0.00509) was much lower than for other ages (0.215 to 0.379$)$. Natural mortality estimates are confounded by fishing gear selectivity in catch-at-age models such as those used in the present study (Schnute \& Richards 1995, Fu \& Quinn 2000). In the present study, gear-selectivity parameters could be uncertain for age 0.1 fish, as a small number of chum salmon $<400 \mathrm{~mm}$ in fork length, mainly age 0.1 fish (Fig. 3), were caught by research gear in the gearselectivity estimation (Fukuwaka et al. 2008). In the sensitivity analysis to trawl selectivity, the mortality estimate for age 0.1 fish under a constant large value (i.e. the upper confidence limit) of $50 \%$ selection length of the research trawl $\left(l_{c}\right)$ was similar to previously reported values for immature chum salmon (Parker 1962a,b, Ricker 1976). Because the number of returns and natural mortality were used in the backward calculation of abundances at immature ages, the underestimation of mortality for age 0.1 fish could have resulted in an underestimation of abundance and biomass at age 0.1 . Total biomass estimates were larger at a large $l_{C}$ value in the sensitivity analysis than the estimates for the initial model. Uncertainty regarding gear-selectivity parameters could cause an underestimation of immature chum salmon biomass.

The uncertainty in gear selectivity might be caused by the difference in vertical distribution among age groups of immature chum salmon. By August, age 0.1 immature chum salmon in the Bering Sea have mixed horizontally with older fish, whereas the spatial distribution of age 0.1 fish in the spring is distinct from that of older fish (Neave et al. 1976). Immature chum salmon are distributed in a shallow zone in the ocean (Walker et al. 2007). Although the difference in vertical distribution of immature chum salmon among age groups has not been fully explored in the oceanic environment, Sakai et al. (1996) assumed that age 0.1 chum or pink salmon inhabited shallower zones than older fish and explained the shallower distribution of salmon in the western North Pacific than in eastern waters. Ueno et al. (2004) showed that the RV 'Kaiyo Maru' midwater trawl which we used in the present study was largely unsuccessful in catching a surface pelagic fish, Pacific saury Cololabis saira, because the fish avoided the hull of the research vessel. Therefore the 
midwater trawl used in the present study might catch less immature chum salmon at age 0.1 near the surface than older fish.

Mortality and abundance estimates for immature chum salmon older than age 0.1 seem to be less affected by uncertain gear selectivity for smaller fish. Natural mortality of marine fish was sometimes assumed to decrease with age or body size (e.g. Ursin 1967, Ricker 1976, Lorenzen 1996). In the present study, juvenile mortality (2.71 to 3.88 ) from release to autumn at age 0.1 (i.e. ca. 17 mo) was much greater than for other ages. This was consistent with previous literature reporting high early mortality after the release of hatchery-reared chum salmon (Bax 1983, Fukuwaka \& Suzuki 2002). Mortality estimates for age 0.2 to 0.5 fish were similar to previous estimates of ocean natural mortality for chum salmon (Parker 1962a,b, Ricker 1976; Table 2) and did not show a significant trend with age. The mortality of hatcheryreared chum salmon may be very high in early ocean life but low in immature stages in offshore waters.

\section{Biomass and roles of chum salmon in the Bering Sea pelagic ecosystem}

The chum salmon biomass estimated from the present study was less than one-tenth of the maximum biomass of walleye pollock in the 1980s (Table 5). Walleye pollock was the dominant planktivore in the Bering Sea basin during summer in the 1980s (Brodeur et al. 1999, Shuntov et al. 1999). The huge biomass of walleye pollock in the basin area was supported by reproduction mainly in the Bogoslof region in the southeastern part of the Bering Sea basin (Yanagimoto et al. 2002). The biomass of walleye pollock in the Bogoslof region declined steeply in the 1990s from $1289006 \mathrm{t}$ in 1991 to $301402 \mathrm{t}$ in 2000, and has been relatively stable at about $250000 \mathrm{t}$ in the 2000s (Ianelli et al. 2008). Simultaneously, the distribution of walleye pollock was diminished in the southeastern part of the Aleutian Basin (Yanagimoto et al. 2002). In the present study, the weight of walleye pollock caught by research trawls was much lower than that of chum salmon in the basin area, and the catchability could be different for these 2 species (Azumaya et al. 2003). Chum salmon abundance has increased since the 1980s (Fukuwaka et al. 2007) and chum salmon is now the dominant pelagic fish in the Bering Sea basin in the summer (Zavolokina \& Zavolokin 2008). However, the biomass of chum salmon has not approached the maximum biomass level of walleye pollock in the 1980s.

Other planktivorous fishes, such as pink salmon and Atka mackerel, are also prevalent in the pelagic ecosystem of the Bering Sea (Brodeur et al. 1999, Shuntov et al. 1999). When pink salmon were highly abundant in the high seas of the Bering Sea in the summers of odd-numbered years, chum salmon changed their distribution or prey selection (Tadokoro et al. 1996, Azumaya \& Ishida 2000). Although biomass estimates were less available for pink salmon, their biomass may be similar to or larger than the chum salmon biomass in the Bering Sea basin, as the maximum catch per unit effort (CPUE) of pink salmon in the 1990s exceeded the maximum CPUE of chum salmon (Azumaya \& Ishida 2000). Biomass estimates of Atka mackerel in the Aleutian Island region were similar to the biomass estimates of chum salmon (Table 5), but the biomass of Atka mackerel migrating in the basin area may be lower than the biomass estimates. Whereas juvenile and immature Atka mackerel were caught widely in the basin area of the Bering Sea (Azumaya et al. 2003), mature fish are distributed in nearshore regions of the Aleutian Islands for nesting during summer to autumn (Lauth et al. 2007).

Mesopelagic organisms, such as myctophid and bathylagid fishes and gonatid squid, may comprise a key group in the bioenergetic flow through pelagic

Table 5. Biomass estimates of dominant planktivorous nekton species in the pelagic ecosystem of Bering Sea basin

\begin{tabular}{|lclcl|}
\hline Species group & Biomass $\left(\times 10^{3} \mathrm{t}\right)$ & Region & Year & Source \\
\hline Chum salmon & $742 ; 617$ & Basin area & $2002 ; 2003$ & Present study \\
& $146-685$ & Western Bering Sea & $2002-2006$ & Zavolokina \& Zavolokin (2008) \\
Walleye pollock & $1140-7626$ & Basin area & $1985-1991$ & Wespestad (1993) \\
& $198-2396$ & Bogoslof & $1988-2007$ & Ianelli et al. (2008) \\
& $2.4-710$ & Western Bering Sea & $2002-2006$ & Zavolokina \& Zavolokin (2008) \\
Atka mackerel & $366-887$ & Aleutian Islands & $1991-2006$ & Lowe et al. (2008) \\
& $3.6-282$ & Western Bering Sea & $2002-2006$ & Zavolokina \& Zavolokin (2008) \\
Mesopelagic fishes & 5921 & Central and western Bering Sea & 1989 & Balanov \& Il'inskii (1992) \\
& $0.16-282$ & Western Bering Sea & $2002-2006$ & Zavolokina \& Zavolokin (2008) \\
Pelagic squid & $592-1302$ & Central and western Bering Sea & $1989-1990$ & Radchenko (1992) \\
& $123-334$ & Western Bering Sea & $2002-2006$ & Zavolokina \& Zavolokin (2008) \\
\hline
\end{tabular}


ecosystems in the Bering Sea basin. These organisms prey mainly on zooplankton, migrate vertically from the surface to deeper layers, and are consumed by marine mammals, seabirds, walleye pollock, Atka mackerel, and Pacific salmon (Davis et al. 1998, Mito et al. 1999, Sinclair et al. 1999, Yang 1999). The maximum biomass estimate for mesopelagic fishes was similar to that for walleye pollock (Table 5); however, in recent years, the biomass of these fishes was smaller than that of chum salmon in the western Bering Sea (Zavolokina \& Zavolokin 2008). The estimated biomass of pelagic squid was lower than the maximum biomass of walleye pollock, but similar to the biomass of chum salmon (Table 5). For chum salmon, these mesopelagic small planktivores may play dual roles as both competitors and prey organisms in the pelagic ecosystem of the Bering Sea basin.

In summary, the estimated biomass of chum salmon was much less than the historical biomass of walleye pollock in the pelagic Bering Sea, although chum salmon have been the dominant pelagic planktivorous nekton in recent years (Zavolokina \& Zavolokin 2008). Because the biomass of mesopelagic organisms was not assessed in the present study, the decline in total biomass of planktivores in the pelagic Bering Sea since the 1980s cannot be fully quantified. However, planktivorous Pacific salmon including chum and pink salmon may play significant roles as competitors and predators of small planktivores. To exploit biological resources based on the productivity of the pelagic Bering Sea, we must determine the role of Pacific salmon in the ecosystem dynamics and nekton community structure, which is one of the objectives of the NPAFC BASIS plan (NPAFC 2001).

Acknowledgements. We thank Captain J. Doi (retired), and the officers, crew, and scientists on board the RV 'Kaiyo Maru' for their help in collecting data and samples. This study was supported by the Promotion Program for International Resources Surveys of the Fisheries Agency of Japan.

\section{LITERATURE CITED}

Aydin K, Mueter F (2007) The Bering Sea: a dynamic food web perspective. Deep-Sea Res II 54:2501-2525

Azumaya T, Ishida Y (2000) Density interactions between pink salmon (Oncorhynchus gorbuscha) and chum salmon (O. keta) and their possible effects on distribution and growth in the North Pacific Ocean and Bering Sea. North Pac Anadromous Fish Comm Bull 2:165-174

Azumaya T, Urawa S, Yamamura O, Fukuwaka M and others (2003) Results of the survey by Kaiyo maru in the Bering Sea, 2002. NPAFC Doc. 717. Hokkaido National Fisheries Research Institute, Fisheries Research Agency, Kushiro

Balanov AA, Il'inskii EN (1992) Species composition and biomass of mesopelagic fishes in the Sea of Okhotsk and the Bering Sea. J Ichthyol 32:85-93

Bax NJ (1983) Early marine mortality of marked juvenile chum salmon (Oncorhynchus keta) released into Hood
Canal, Puget Sound, Washington, in 1980. Can J Fish Aquat Sci 40:426-435

Bolker BM, Okuyama T, Bjorndal KA, Bolten AB (2007) Incorporating multiple mixed stocks mixed stock analysis: 'many-to-many' analyses. Mol Ecol 16:685-695

Brodeur RD, Wilson MT, Walters GE (1999) Foraging fishes in the Bering Sea: distribution, species associations, and biomass trends. In: Loughlin TR, Ohtani K (eds) Dynamics of the Bering Sea. University of Alaska Sea Grant, AK-SG99-03, Fairbanks, AK, p 509-536

Clark JS (2007) Models for ecological data: an introduction. Princeton University Press, Princeton, NJ

Davis ND, Myers KW, Ishida Y (1998) Caloric value of highseas salmon prey organisms and simulated salmon ocean growth and prey consumption. North Pac Anadromous Fish Comm Bull 1:146-162

FRA (Fisheries Research Agency) (2008) Database on biological assessment of Pacific salmon populations in Japan. Salmon Database 15. FRA, Yokohama

FRA (in press) Database on biological assessment of Pacific salmon populations in Japan. Salmon Database 16(1). FRA, Yokohama

> Fu C, Quinn TJ II (2000) Estimability of natural mortality and other population parameters in a length-based model: Pandalus borealis in Kachemak Bay, Alaska. Can J Fish Aquat Sci 57:2420-2432

> Fukuwaka M, Morita K (2008) Increase in maturation size after the closure of a high seas gillnet fishery on hatcheryreared chum salmon Oncorhynchus keta. Evol Appl 1: 376-387

Fukuwaka M, Suzuki T (2002) Early sea mortality of markrecaptured juvenile chum salmon in open coastal waters. J Fish Biol 60:3-12

Fukuwaka M, Azumaya T, Nagasawa T, Starovoytov AN, Helle JH, Saito T, Hasegawa E (2007) Trends in abundance and biological characteristics of chum salmon. North Pac Anadromous Fish Comm Bull 4:35-43

Fukuwaka M, Azumaya T, Davis ND, Nagasawa T (2008) Bias in size composition of chum salmon (Oncorhynchus keta) caught by a gillnet with a geometric series of mesh sizes, and its correction using gear intercalibration. ICES J Mar Sci 65:930-936

Gelman A, Rubin DB (1992) Inference from iterative simulation using multiple sequences. Stat Sci 7:457-511

Groot C, Margolis L (eds) (1991) Pacific salmon life histories. UBC Press, Vancouver, BC

> Heidelberger P, Welch PD (1983) Simulation run length control in the presence of an initial transient. Operations Res 31:1109-1144

Hiroi O (1998) Historical trends of salmon fisheries and stock conditions in Japan. North Pac Anadromous Fish Comm Bull 1:23-27

Ianelli JN, Honkalehto T, Barbeaux SJ (2008) Abbreviated assessment of pollock (Theragra chalcogramma) from the Bogoslof Island region. In: Stock assessment and fishery evaluation report for the groundfish resources of the Bering Sea/Aleutian Islands regions. North Pacific Fishery Management Council, Anchorage, AK, p 217-220

Ishida Y, Ito S, Ueno Y, Sakai J (1998) Seasonal growth patterns of Pacific salmon (Oncorhynchus spp.) in offshore waters of the North Pacific Ocean. North Pac Anadromous Fish Comm Bull 1:66-80

Lauth RR, McEntire SW, Zenger HH Jr (2007) Geographic distribution, depth range, and description of Atka mackerel Pleurogrammus monopterygius nesting habitat in Alaska. Alsk Fish Res Bull 12:165-186

Livingston P (2004) Bering Sea. In: Marine ecosystems of 
the North Pacific. PICES Spec Publ 1. North Pacific Marine Science Organization, Sidney, British Columbia, p 141-151

Lorenzen K (1996) The relationship between body weight and natural mortality in juvenile and adult fish: a comparison of natural ecosystems and aquaculture. J Fish Biol 49: 627-647

Lowe S, Ianelli J, Wilkins M, Aydin K, Lauth R, Spies I (2008) Stock assessment of Bering Sea/Aleutian Islands Atka mackerel. In: Stock assessment and fishery evaluation report for the groundfish resources of the Bering Sea/Aleutian Islands regions. North Pacific Fishery Management Council, Anchorage, AK, p 1119-1198

> Lunn DJ, Thomas A, Best N, Spiegelhalter D (2000) WinBUGS: a Bayesian modelling framework: concepts, structure, and extensibility. Stat Comput 10:325-337

McRoy CP, Goering JJ (1975) Primary production budget for the Bering Sea. In: Hood DW, Takenouchi Y (eds) Bering Sea oceanography: an update 1972-1974. Report 75-2, Institute of Marine Science, University of Alaska, Fairbanks, AK, p 97-107

Michielsens CGJ, McAllister MK, Kuikka S, Mäntyniemi S and others (2008) Combining multiple Bayesian data analyses in a sequential framework for quantitative fisheries stock assessment. Can J Fish Aquat Sci 65:962-974

Mito K, Nishimura A, Yanagimoto T (1999) Ecology of groundfishes in the eastern Bering Sea, with emphasis on food habits. In: Loughlin TR, Ohtani K (eds) Dynamics of the Bering Sea. AK-SG-99-03, University of Alaska Sea Grant, Fairbanks, AK, p 537-580

Moriya S, Sato S, Azumaya T, Suzuki O, Urawa S, Urano A, Abe $S$ (2007) Genetic stock identification of chum salmon in the Bering Sea and North Pacific Ocean using mitochondrial DNA microarray. Mar Biotechnol 9:179-191

Murphy J, Davis N, Ivanov O, Rohr M, Elmajjati S, Barber W (2003) Cruise report of the 2002 F/V Northwest Explorer BASIS survey in the Bering Sea, September-October. NPAFC Doc 676, Rev 1, National Marine Fisheries Service, Auke Bay Laboratory, Juneau, AK

Myers KW, Aydin KY, Walker RV, Fowler S, Dahlberg ML (1996) Known ocean ranges of stocks of Pacific salmon and steelhead as shown by tagging experiments, 1956-1995. NPAFC Doc 192, University of Washington, Fisheries Research Institute, Seattle, WA

NSRC (National Salmon Resources Center) (2001) Database on juvenile Pacific salmon released from Japan. Salmon Database 9(2). NRSC, Sapporo

NSRC (2002) Database on juvenile Pacific salmon released from Japan. Salmon Database 10(2). NSRC, Sapporo

NSRC (2003) Database on juvenile Pacific salmon released from Japan. Salmon Database 11(2). NSRC, Sapporo

NSRC (2004) Database on biological assessment of Pacific salmon populations in Japan. Salmon Database 12(1). NSRC, Sapporo

NSRC (2005) Database on biological assessment of Pacific salmon populations in Japan. Salmon Database 13(1). NSRC, Sapporo

NSRC (2006) Database on biological assessment of Pacific salmon populations in Japan. Salmon Database 14(1). NSRC, Sapporo

Neave F, Yonemori T, Bakkala RG (1976) Distribution and origin of chum salmon in offshore waters of the North Pacific Ocean. Bull Int North Pac Fish Comm 35:1-79

NPAFC (North Pacific Anadromous Fish Commission) (2001) Plan for NPAFC Bering-Aleutian Salmon International Survey (BASIS) 2002-2006. NPAFC Doc 579, Rev 2, NPAFC, Vancouver, BC
Parker RR (1962a) A concept of the dynamics of pink salmon populations. In: Wilimovsky NJ (ed) Symposium on pink salmon. Institute of Fisheries, University of British Columbia, Vancouver, BC, p 203-211

Parker RR (1962b) Estimations of ocean mortality rates for Pacific salmon (Oncorhynchus). J Fish Res Board Canada 19:561-589

Plummer M, Best N, Cowles K, Vines K (2009) Coda: output analysis and diagnostics for MCMC. R package version 0.13-4. Accessed 1 Aug. www.R-project.org

R Development Core Team (2008) R: a language and environment for statistical computing. R Foundation for Statistical Computing, Vienna, Austria

Radchenko VI (1992) The role of squids in the pelagic ecosystem of the Bering Sea. Oceanology 32:762-767

Ricker WE (1976) Review of the rate of growth and mortality of Pacific salmon in salt water, and noncatch mortality caused by fishing. J Fish Res Board Canada 33:1483-1524

Sakai J, Ueno Y, Ishida Y (1996) Vertical distribution of salmon determined by an acoustic survey in the North Pacific Ocean in the winter of 1996. NPAFC Doc. 214, National Research Institute of Far Seas Fisheries, Shimizu

Sato S, Kojima H, Ando J, Ando H and others (2004) Genetic population structure of chum salmon in the Pacific Rim inferred from mitochondrial DNA sequence variation. Environ Biol Fishes 69:37-50

Schnute JT, Richards LJ (1995) The influence of error on population estimates from catch-age models. Can J Fish Aquat Sci 52:2063-2077

Seeb LW, Crane PA, Kondzela CM, Wilmot RL, Urawa S, Varnavskaya NV, Seeb JE (2004) Migration of Pacific Rim chum salmon on the high seas: insights from genetic data. Environ Biol Fishes 69:21-36

Shuntov VP, Dulepova EP, Lapko VV (1999) Long-term variations in pelagic communities in the large marine ecosystems of the Northwest Pacific Ocean. In: Sherman K, Tang Q (eds) Large marine ecosystems of the Pacific Rim: assessment, sustainability, and management. Blackwell Science, Malden, MA, p 48-55

Sinclair EH, Balanov AA, Kubodera T, Radchenko VI, Fedorets YA (1999) Distribution and ecology of mesopelagic fishes and cephalopods. In: Loughlin TR, Ohtani K (eds) Dynamics of the Bering Sea. University of Alaska Sea Grant, AK-SG-99-03, Fairbanks, AK, p 485-508

Starovoytov AN (2007) Trends in abundance and feeding of chum salmon in the western Bering Sea. North Pac Anadromous Fish Comm Bull 4:45-51

Sturtz S, Ligges U, Gelman A (2005) R2WinBUGS: a package for running WinBUGS from R. J Stat Softw 12:1-16

Tadokoro K, Ishida Y, Davis ND, Ueyanagi S, Sugimoto T (1996) Change in chum salmon (Oncorhynchus keta) stomach contents associated with fluctuation of pink salmon (O. gorbuscha) abundance in the central subarctic Pacific and Bering Sea. Fish Oceanogr 5:89-99

Tanaka S, Shepard MP, Bilton HT (1969) Origin of chum salmon (Oncorhynchus keta) in offshore waters of the North Pacific in 1956-1958 as determined from scale studies. Bull Int North Pac Fish Comm 26:57-155

Ueno Y, Suyama S, Kurita Y, Kumazawa T (2004) Design and operation methods of a mid-water trawl for quantitative sampling of a surface pelagic fish, Pacific saury (Cololabis saira). Fish Res 66:3-17

Urawa S, Kawana M, Anma G, Kamei Y and others (2000) Geographic origin of high-seas chum salmon determined by genetic and thermal otolith markers. North Pac Anadromous Fish Comm Bull 2:283-290

Urawa S, Ueno Y, Ishida Y, Seeb LW, Crane PA, Abe S, Davis 
ND (2001) A migration model of Japanese chum salmon during early ocean life. North Pac Anadromous Fish Comm Tech Rep 2:1-2

Ursin E (1967) A mathematical model of some aspects of fish growth, respiration, and mortality. J Fish Res Board Canada 24:2355-2453

Walker RV, Sviridov VV, Urawa S, Azumaya T (2007) Spatiotemporal variation in vertical distributions of Pacific salmon in the Ocean. North Pac Anadromous Fish Comm Bull 4:193-201

Wespestad VG (1993) The status of Bering Sea pollock and the effect of the 'Donut Hole' fishery. Fisheries 18:18-24

Editorial responsibility: Nicholas Tolimieri, Seattle, Washington, USA
Yanagimoto T, Nishimura A, Mito K, Takao Y, Williamson NJ (2002) Interannual changes of biological properties of walleye pollock Theragra chalcogramma in the central Bering Sea. Prog Oceanogr 55:195-208

Yang MS (1999) The trophic role of Atka mackerel, Pleurogrammus monopterygius, in the Aleutian Islands area. Fish Bull 97:1047-1057

Zavolokina EA, Zavolokin AV (2008) Distribution, biomass and age composition of chum salmon (Oncorhynchus keta) in the western Bering Sea in 2002-2006. NPAFC Doc. 1121, Pacific Scientific Research Fisheries Centre (TINRO center), Vladivostok

Submitted: May 11, 2009; Accepted: December 16, 2009 Proofs received from author(s): March 2, 2010 